\title{
USING SAVING LIGHT BULBS AS ECONOMICAL ALTERNATIVE LIGHT SOURCE FOR RAISING DANDARAWI CHICKEN
}

\author{
M.F.A. Farghly and M. A. Abdelnabi
}

Department of Animal and poultry Production, Faculty of Agriculture, University of Assiut, Egypt

\section{SUMMARY}

Seven hundred and twenty, four weeks old Dandarawi chicks were used to study the effects of light source on their productive and reproductive performance. Chicks were divided into 3 equal groups (240 birds each) and housed in floor pens. The first group was used as control and reared under incandescent light bulbs (IL), while the second and third groups were reared under fluorescent (FL) and saving light bulbs (SL), respectively. All birds were raised under photoperiod of 12 and 16 hours per day during the growing and laying periods, with light intensities of 5-10 and 10-25 Luxes, respectively. Feed and water were available ad lib.and all the other conditions were the same during the experimental period. Results showed that birds reared under $S L$ and $F L$ bulbs had significantly $(P \leq 0.05)$ higher body weight $(B W)$, daily weight gain $(B W G)$, egg yolk index, liver and giblets percentages than the control group. Also, egg shell thickness of birds reared under SL bulbs significantly increased $(P \leq 0.05)$ compared to birds reared under FL and IL bulbs. In addition, birds reared under IL bulbs had significantly $(P \leq 0.05)$ higher egg number, hen day production (HDP) and ovary percentages as compared to the other two groups. No significant differences $(P \leq 0.05)$ were found between groups in leg problems, carcass traits, testes percentage, egg weight and fertility and hatchability. Finally, the economical efficiency of the birds reared under FL and SL bulbs was better than the IL groups during the growing period by 26.4 and 36.1\%, respectively. However, the economical efficiency of the birds reared under IL light bulbs was better than the FL and SL groups during laying period by 12.9 and $11.4 \%$ as well as by 4.1 and $1.4 \%$ for table and fertile eggs, respectively.

Keywords: productive and reproductive performance, light source, Dandarawi chicken

\section{INTRODUCTION}

Poultry performance is influenced by their genetic make up and the surround environment such as light (Morris, 2004). Increased environmental complexity in poultry management facilities is recognized as a means to achieve productivity goals and to resolve welfare concerns (Newberry, 1995; Wemelsfelder and Birke, 1997 and Mench, 1998). The managerial factors are the most important factors that improve bird performance and minimize the production costs. As electricity costs have continued to rise, poultry producers have searched for alternative ways to reduce electricity consumption and maintain bird performance. In environment-controlled houses, birds are exposed only to artificial light. Thus source, spectra, intensity and

Issued by The Egyptian Society of Animal Production 
regimen of light supplementation are considered major factors in poultry management (Andrews and Zimmerman, 1990).

Light sources have different spectral distribution patterns and the decision to install one over the other depends on factors such as energy efficiency, heat out-put, cost of the bulb, and its life expectancy. Typically, incandescent bulbs were common in poultry houses. However, there has recently been a trend towards the use of fluorescent bulbs or other light sources because of their longer life and lower costs. The incandescent bulb is the current standard by which other light sources are compared. They have a light efficiency of about $8-24$ lumens per watt and a rated life of about 750-2000 hours. The fluorescent bulbs come in 5, 7, 9, 13, 16, 22, and 28 watt sizes with efficiencies of 50 to 69 lumens per watt and rated lifetimes of greater than 10,000 hours (Darre and Rock, 1995). The fluorescent lamps have been used successfully in all types of poultry operations, including caged layers, (Darre, 1986) growing broilers (Andrews and Zimmerman, 1990; Scheideler, 1990), growing pullets and turkeys. Research on Leghorn layers indicated a preference for fluorescent lamps over incandescent lamps (Widowski et al., 1992). Recently, saving bulbs is considered the most efficient in illuminating large areas and less electricity costs by about $80 \%$. Saving light lamps have ratings from 5 to 36 watts and they have efficiencies of about 80 to 100 lumens per watt and are rated at about 10,000 to 20,000 hours of lifetime.

The previous facts are important when selecting a light source for illuminating poultry houses. As a result, many lighting manipulations were used in poultry production such as lighting period, color, wavelength, and source to improve the poultry performance and minimize the production costs. In modern poultry houses, artificial illumination may be the only source of light provided to birds; thus, the duration, intensity, and quality of light become important environmental factors, as light influences both reproductive and productive of bird as well as costs. Therefore, the objective of this experiment was to study the impact of using saving light bulbs, as an economical alternative light source for raising Dandarawi chickens.

\section{MATERIALS AND METHODS}

The present work was carried out at the Research Poultry Farm, Animal and Poultry Production Department, Faculty of Agriculture, Assiut University. Seven hundred and twenty, four weeks old Dandarawi chicks were used to study the effects of light source on growth performance, carcass quality, gonad weights, leg problems, mortality rate and economical efficiency. Chicks were divided into 3 equal groups ( 3 replicates of 80 birds each) and housed in floor pens. The first group was used as a control and reared under incandescent light bulbs (IL), while the second and third groups were reared under fluorescent (FL) and saving light bulbs (SL), respectively. All birds were raised under photoperiod of 12 and 16 hours per day during the growing and laying periods, with light intensities of 5-10 and 10-25 Luxes, respectively. Feed and water were available $a d$ lib.and all the other conditions were the same during the experimental period (4- 36 weeks of age). All sources of natural light were covered by heavy cotton black curtains and blackout plastic curtains which completely prevented any source of natural light. Birds received growing and laying diets from 4-20 and 21-36 weeks of age, respectively. The composition and calculated analysis of the experimental diets are shown in Table (1). 
Table 1. Composition and calculated analysis of experimental diet

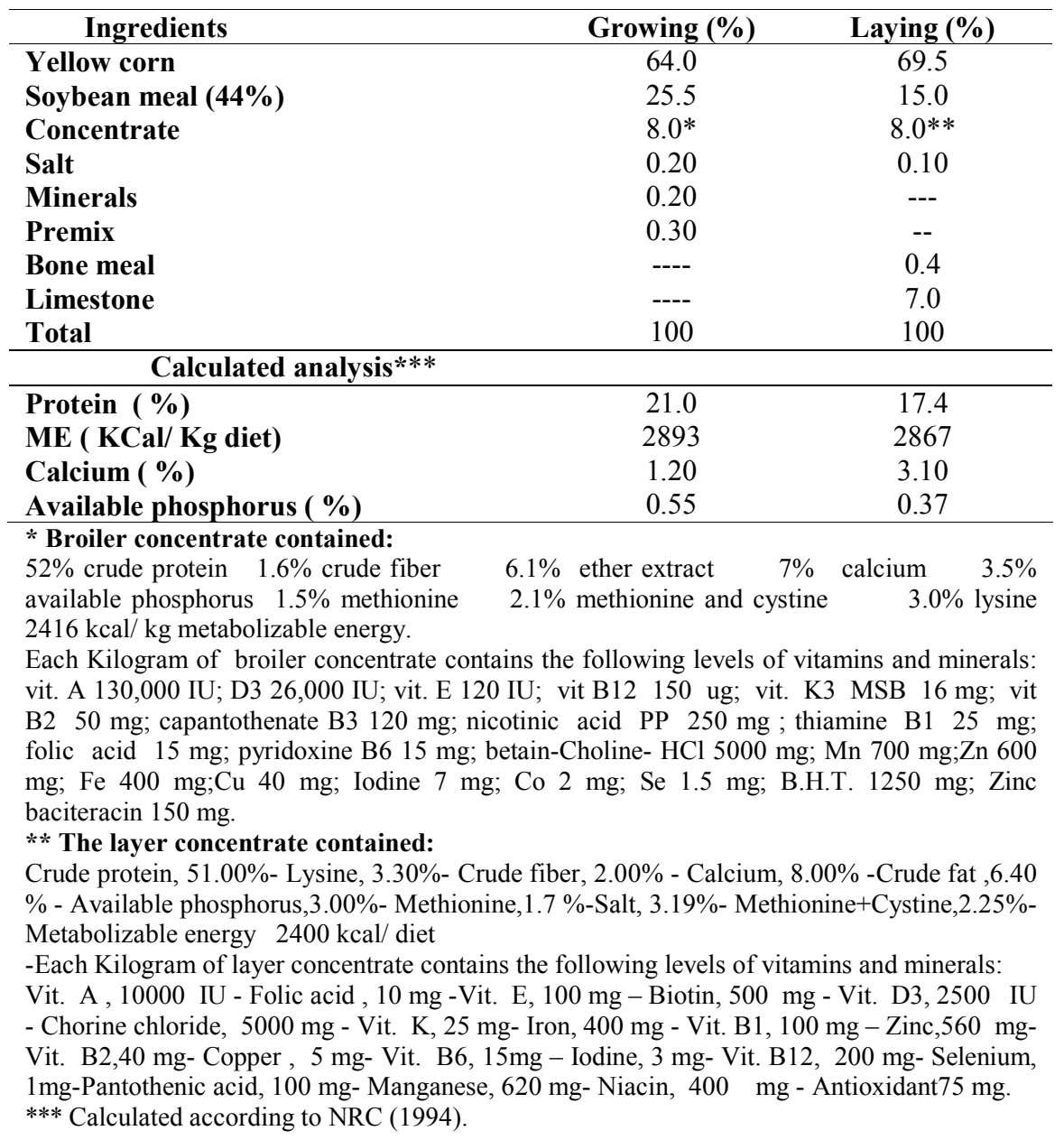

Body weight (BW) and feed consumption (FC) were recorded weekly and calculated periodically every 2 weeks. Feed conversion ratio; (FCRg): ( $\mathrm{g}$ feed/ g gain) was calculated weekly by dividing the total feed consumed every 2 weeks $(\mathrm{g} / \mathrm{d} / \mathrm{h})$ in a pen by the total weight gain $(\mathrm{g} / \mathrm{d} / \mathrm{h})$ of its birds. Also, the feed conversion ratio values ( $\mathrm{g}$ feed/g egg mass, FCRe) were calculated periodically every four weeks, from 24 to 36 weeks of age. At 20 weeks of age, 9 birds per group ( 3 from each replicate) were randomly chosen and slaughtered. The internal organs were removed while the heart, liver, empty gizzard, testes and ovary including the yellow follicles, were weighed. Each of head at the occipital bone, feet and shanks at the hock joints, wings at shoulder joints, neck close to the shoulder, breast, femurs and drumsticks were weighed as separate carcass parts. Each of carcass weight, feet and 
shank, head, neck, drumsticks, femurs, drumsticks and femurs, breast, wings and back were calculated as percentages of pre-slaughter live body weight, while each of heart, liver, gizzard, giblets, testes and ovary were calculated as percentages of carcass weight. The ovarian weight included the weight of the three largest follicles.

Egg weight, egg number and egg mass and egg production as hen-day egg production (HDP) were counted and recorded periodically every four weeks, from 24 to 36 weeks of age. Dead birds were recorded daily and expressed as percentage during the experimental period. During the period from 24 to 36 weeks of the experiment, 60 fresh-laid eggs were taken, every four weeks, from each group to measure egg quality characteristics. Egg weight was recorded to the nearest 0.1 gram on the same day of collection using electronic scale. The length and width of each egg were determined using a sliding caliper and their egg shape index was determined according to Reddy et al. (1979). Egg shape indexes= (width of egg/length of egg)x 100. All eggs were broken gently on a glass surface. The height of thick albumen and yolk were measured using a micrometer, as described by Brant and Shrader (1952). The diameter of yolk was measured, using a sliding caliper. The yolk was separated from the albumen and weighted. Shells with membranes were dried and weighed to the nearest $0.01 \mathrm{gm}$. Haugh units were calculated individually from the egg weight and albumen height (Doyon et al., 1986). Haugh unit values were calculated for each egg using the formula: Haugh unit $=100 \log (\mathrm{H}-1.7 \mathrm{x} \mathrm{W}$ $0.37+7.6)$ Where: $\mathrm{H}=$ the observed height of the albumen in millimeters and $\mathrm{W}=$ weight of egg (g). Also, the yolk index was calculated by dividing (yolk's height/ yolk's diameter) x100. Shell thickness of the dried shell (without membranes) was measured using shell thickness apparatus (millimeters). Egg components were expressed as percentages of the egg weight. Four hatches were obtained using Paterzime setter at 24, 28, 32 and 36 weeks of age. Fertility and hatchability percentages were calculated as follow: Fertility $(\%)=($ Fertile eggs $) \times 100 /$ Total eggs set \& True hatchability $(\%)=($ Viable hatched chicks) $x 100 /$ fertile eggs.

Economical efficiency (EE): Feed cost per bird was calculated by multiplying mean FC per bird by the cost of $1 \mathrm{~kg}$ of diet. Bird price was calculated by multiplying mean bird weight by price of $1 \mathrm{~kg}$ of live weight. The net revenue per bird is estimated as the difference between the total income/bird (LE), (growth, table and fertile egg production) and the total costs of feed and light costs. Economical efficiency (EE) was estimated by dividing net revenue by total feed and light costs. Statistical analysis: Data collected were subjected to ANOVA by applying the General Linear Models Procedure of SAS software (SAS institute, version 6.12, 1996). Duncan (1955) was used to detect differences among means of different groups. Significance was set at the $5 \%$ level. The following model was used for analysis of variance: $\mathbf{Y}_{\mathrm{ij}}=\boldsymbol{\mu}+\mathbf{S}_{\mathbf{i}}+\mathbf{e}_{\mathbf{i j}}$

Where: $\quad$ Yij $=$ observation, $\quad \mu=$ overall mean, $\mathrm{Si}=$ treatment effect, $\quad$ e $\mathrm{ij}=$ experimental errors.

\section{RESULTS AND DISCUSION}

Body weight $(B W)$ and body weight gain $(B W G)$ :

The results presented in Table (2), showed significant differences $(\mathrm{P} \leq 0.05)$ in $\mathrm{BW}$ for all the experimental groups, control (c), treatment 1 (T1) or treatment 2 (T1) at all studied ages except at 4, 6 and 36 weeks of age. FL and SL groups had significantly $(\mathrm{P} \leq 0.05)$ higher BW than those of IL group at $8,10,18$ and 20 weeks of age by 3.9, 2.3, 7.9 and $6.7 \%$ as well as $4.8,3.1,6.4$ and $5.4 \%$, respectively. BW of the SL group was significantly $(\mathrm{P} \leq 0.05)$ higher than those of IL and FL groups at 12,14 and 
16 weeks of age by $2.9,2.8$ and $2.6 \%$ as well as $14.1,7.8$ and $8.7 \%$, respectively. Also, BW of the FL group was significantly $(\mathrm{P} \leq 0.05)$ higher than those of IL group at 12,14 and 16 weeks of age by $11.5,6.0$ and $5.4 \%$, respectively. Birds of FL and SL groups gained significantly $(\mathrm{P} \leq 0.05)$ more than those of IL group at $6-8,10-12$, and 12-14 weeks of age, by $11.4,4.2$ and $20.7 \%$ as well as $11.7,28.2$ and $20.7 \%$, respectively. No significant differences were found between the BW of the FL and SL groups. Birds of FL group gained significantly $(\mathrm{P} \leq 0.05)$ more weight than those of IL and SL groups at 16-18 weeks of age by 37.7 and $42.5 \%$, respectively. However, the overall mean of FL and SL groups showed a significantly $(\mathrm{P} \leq 0.05)$ higher daily weight gain than those of IL group by 6.9 and $5.6 \%$, respectively.

Table 2. Means \pm SE of body weight and body weight gain of Dandarawi chickens as affected by light source

\begin{tabular}{|c|c|c|c|c|}
\hline \multirow{2}{*}{ Traits } & \multirow{2}{*}{$\begin{array}{c}\text { Age } \\
\text { (wks) }\end{array}$} & \multicolumn{3}{|c|}{ Treatments } \\
\hline & & $\mathrm{C}$ & T1 & T2 \\
\hline \multirow{10}{*}{ Body weight (g) } & 4 & $164.0 \pm 1.4$ & $166.81 \pm 1.4$ & $166.20 \pm 1.7$ \\
\hline & 6 & $235.7 \pm 2.0$ & $234.91 \pm 2.1$ & $238.00 \pm 2.1$ \\
\hline & 8 & $351.9 \pm 2.9^{\mathrm{b}}$ & $366.10 \pm 3.8^{\mathrm{a}}$ & $369.60 \pm 3.4^{\mathrm{a}}$ \\
\hline & 10 & $530.4 \pm 4.0^{\mathrm{b}}$ & $542.70 \pm 4.9^{\mathrm{a}}$ & $547.20 \pm 5.3^{\mathrm{a}}$ \\
\hline & 12 & $833.53 \pm 5.0^{\mathrm{c}}$ & $858.80 \pm 5.6^{\mathrm{b}}$ & $970.40 \pm 5.0^{\mathrm{a}}$ \\
\hline & 14 & $1057.8 \pm 6.2^{\mathrm{c}}$ & $1088.71 \pm 7.2^{b}$ & $1158.50 \pm 6.7^{\mathrm{a}}$ \\
\hline & 16 & $1181.5 \pm 6.4^{\mathrm{c}}$ & $1212.43 \pm 7.3^{b}$ & $1282.13 \pm 7.0^{\mathrm{a}}$ \\
\hline & 18 & $1316.0 \pm 6.1^{\mathrm{b}}$ & $1428.15 \pm 11.0^{\mathrm{a}}$ & $1406.20 \pm 10.0^{\mathrm{a}}$ \\
\hline & 20 & $1479.8 \pm 6.0^{b}$ & $1585.46 \pm 9.3^{\mathrm{a}}$ & $1563.53 \pm 8.6^{\mathrm{a}}$ \\
\hline & 36 & $1655.44 \pm 10.8$ & $1670.32 \pm 12.1$ & $1665.51 \pm 9.6$ \\
\hline \multirow{8}{*}{$\begin{array}{l}\text { Body weight gain } \\
\text { (g/bird/day) }\end{array}$} & $4-6$ & $5.12 \pm 0.12$ & $4.86 \pm 0.13$ & $5.13 \pm 0.14$ \\
\hline & $6-8$ & $8.30 \pm 0.18^{b}$ & $9.37 \pm 0.26^{\mathrm{a}}$ & $9.40 \pm 0.21^{\mathrm{a}}$ \\
\hline & $8-10$ & $12.80 \pm 0.28$ & $12.55 \pm 0.42$ & $12.70 \pm 0.43$ \\
\hline & $10-12$ & $21.70 \pm 0.37^{b}$ & $22.65 \pm 0.42^{\mathrm{a}}$ & $30.23 \pm 0.42^{\mathrm{a}}$ \\
\hline & $12-14$ & $13.02 \pm 0.37^{\mathrm{b}}$ & $16.42 \pm 0.41^{\mathrm{a}}$ & $16.44 \pm 0.40^{\mathrm{a}}$ \\
\hline & $14-16$ & $8.84 \pm 0.10$ & $8.84 \pm 0.10$ & $8.84 \pm 0.40$ \\
\hline & $16-18$ & $9.60 \pm 0.50^{\mathrm{b}}$ & $15.41 \pm 0.62^{\mathrm{a}}$ & $8.86 \pm 0.67^{b}$ \\
\hline & $18-20$ & $11.70 \pm 0.22$ & $11.24 \pm 0.20$ & $11.24 \pm 0.16$ \\
\hline \multicolumn{2}{|c|}{ Overall mean } & $11.80 \pm 0.10^{b}$ & $12.67 \pm 0.10^{a}$ & $12.50 \pm 0.10^{a}$ \\
\hline
\end{tabular}

a---c Means \pm standard error in the same row with different superscripts are significantly different $(\mathrm{P} \leq 0.05)$.

$\mathrm{C}, \mathrm{T} 1$ and $\mathrm{T} 3=\mathrm{Birds}$ were reared under incandescent, fluorescent and saving light bulbs respectively.

From the obtained findings, it could be noticed that, the average BW of the FL group was similar to that of the SL and both of them exceeded significantly that of the IL group. The obtained results are in agreement with the findings of Denbow et al. (1990), Abdul Ghuffar et al. (2009), Karakaya et al. (2009) who indicated that 
light source affect body weight. Also, Zimmermann (1988) and Hajra et al. (2009) found that FL source provided superior body weight and body weight gain compared to IL light. Light spectra promote growth in broilers and significantly green and blue light increase body weight (Stoianov et al., 1978, Knisley, 1990; Tarihi, 1996; Rozenboim et al., 1999; Rozenboim et al., 2004). In addition, Lewis et al. (2007) found that pullets grown under green light had significantly lighter BW at 6 wk than birds grown under white light. On contrast, Hulan and Proudfoot (1987), Felts et al. (1990), Lewis and Morris (1998), Rodenburg and Middelkoop (2003) and Kristensen et al. (2006) reported that light source had no significant effect on body weight in broilers. Buyse et al. (1996) did not observe any significant effect of light colour or source on growth performance. Broilers reared under blue or green fluorescent light gained more weight than those exposed to red or white light (Wabeck and Skoglund, 1974; Prayitno et al., 1997b; Rozenboim et al. 1998).

\section{Feed consumption (FC) and feed conversion (FCR):}

No significant differences were found in FC among all groups (Table 3). However, at 8-10, 12-14 and 18-20 weeks of age, the birds of IL and FL groups consumed significantly $(\mathrm{P} \leq 0.05)$ more feed than SL group by 10.0 and $10.5 \%$ as well as 3.8 and $6.8 \%$, respectively. Also, at 12-14 weeks of age, the birds of IL group consumed significantly $(\mathrm{P} \leq 0.05)$ more feed than the birds in FL and SL groups by 7.3 and $3.5 \%$, respectively. The overall mean of FC in FL and SL groups were significantly $(\mathrm{P} \leq 0.05)$ higher by about 5.5 and $6.0 \%$, respectively as compared with that of IL groups. No significant differences between the FL and SL groups were observed. At 6-8 and 16-18 weeks of age, FL and SL groups had significantly $(\mathrm{P} \leq 0.05)$ better feed conversion for growth (FCRg) than those of IL group by 14.8 and $17.8 \%$ as well as 37.0 and $17.1 \%$, respectively. Birds of SL group had significantly $(\mathrm{P} \leq 0.05)$ better FCRg by about $25.8 \%$ than those of IL and FL groups by 31.9 and $35.6 \%$, respectively. The average feed conversion $(\mathrm{C}, \mathrm{T} 1$ and $\mathrm{T} 2)$ for egg (FCRe) values showed no significant differences $(\mathrm{P}>0.05)$ in all groups at all ages during the experimental periods.

Partial similar findings were reported by Stoianov et al. (1978); Jones et al. (1982); Siopes (1984); Tarihi (1996), Abdul Ghuffar et al. (2009) and Karakaya et al. (2009) who found that light source and color had significant $(\mathrm{P} \leq 0.05)$ effect on feed consumption and conversion ratio for growth. Also, Denbow et al., (1990) found that light source influenced feed efficiency. While, Hajra et al. (2009) found that fluorescent light source showed significantly lower feed consumption and better feed conversion than those of birds reared under incandescent light. On the other hand, the results are in disagreement with the findings of Kristensen, et al. (2006) and Lewis et al. (2007) who found that light source had no effect on feed intake and feed conversion of broiler chickens. Also, Hulan and Proudfoot (1987), Zimmermann (1988), Leighton et al. (1989), Felts et al. (1990), Rodenburg and Middelkoop (2003) found that light source and no significant $(\mathrm{P} \leq 0.05)$ effect on feed conversion ratio. 
Table 3. Means \pm SE of feed consumption (FC) and feed conversion (FCR) of Dandarawi chickens as affected by light source.

\begin{tabular}{|c|c|c|c|c|}
\hline \multirow{2}{*}{ Traits } & \multirow{2}{*}{$\begin{array}{l}\text { Age } \\
(w k s)\end{array}$} & \multicolumn{3}{|c|}{ Treatments } \\
\hline & & $\mathbf{C}$ & T1 & $\mathbf{T 2}$ \\
\hline \multirow{8}{*}{$\begin{array}{c}\text { FC (g/bird/day) } \\
\text { during growing } \\
\text { period }\end{array}$} & $4-6$ & $26.70 \pm 0.92$ & $27.40 \pm 0.60$ & $25.70 \pm 0.80$ \\
\hline & $6-8$ & $30.13 \pm 1.2$ & $29.50 \pm 1.8$ & $28.40 \pm 1.2$ \\
\hline & $8-10$ & $35.60 \pm 1.0^{\mathrm{a}}$ & $35.40 \pm 0.80^{\mathrm{a}}$ & $32.03 \pm 0.84^{b}$ \\
\hline & $10-12$ & $43.40 \pm 1.1$ & $43.50 \pm 1.8$ & $39.10 \pm 0.80$ \\
\hline & $12-14$ & $49.10 \pm 0.10^{\mathrm{a}}$ & $45.50 \pm 0.81^{\mathrm{b}}$ & $43.93 \pm 1.0^{\mathrm{b}}$ \\
\hline & $14-16$ & $68.10 \pm 1.1$ & $68.73 \pm 1.5$ & $65.70 \pm 1.2$ \\
\hline & $16-18$ & $77.80 \pm 2.4$ & $79.73 \pm 2.5$ & $76.03 \pm 1.6$ \\
\hline & $18-20$ & $89.73 \pm 1.3^{\mathrm{a}}$ & $91.70 \pm 1.2^{\mathrm{a}}$ & $86.30 \pm 1.2^{\mathrm{b}}$ \\
\hline \multirow{5}{*}{$\begin{array}{c} \\
\text { FC (g/bird/day) } \\
\text { during laying } \\
\text { period }\end{array}$} & Overall mean & $\mathbf{5 2 . 6 0} \pm \mathbf{0 . 9 2}{ }^{\mathrm{a}}$ & $\mathbf{5 2 . 7 0} \pm 0.80^{\mathrm{a}}$ & $49.70 \pm 0.40^{b}$ \\
\hline & $20-24$ & $97.30 \pm 0.8$ & $94.73 \pm 1.0$ & $95.20 \pm 0.6$ \\
\hline & $24-28$ & $98.33 \pm 0.9$ & $98.43 \pm 1.0$ & $98.30 \pm 1.0$ \\
\hline & $28-32$ & $105.7 \pm 1.7$ & $103.6 \pm 1.2$ & $103.2 \pm 1.8$ \\
\hline & $32-36$ & $108.3 \pm 0.9$ & $107.0 \pm 2.0$ & $107.7 \pm 1.2$ \\
\hline \multirow{9}{*}{$\begin{array}{c}\text { FCRg } \\
\text { (g feed/g gain) }\end{array}$} & Overall mean & $102.4 \pm 0.40$ & $100.9 \pm 0.90$ & $101.1 \pm 0.30$ \\
\hline & $4-6$ & $5.23 \pm 0.32$ & $5.64 \pm 0.20$ & $5.10 \pm 0.53$ \\
\hline & $6-8$ & $3.66 \pm 0.20^{\mathrm{a}}$ & $3.12 \pm 0.12^{\mathrm{b}}$ & $3.01 \pm 0.13^{\mathrm{b}}$ \\
\hline & $8-10$ & $2.80 \pm 0.10$ & $2.82 \pm 0.10$ & $2.61 \pm 0.33$ \\
\hline & $10-12$ & $2.02 \pm 0.12^{\mathrm{a}}$ & $1.91 \pm 0.10^{\mathrm{a}}$ & $1.30 \pm 0.04^{b}$ \\
\hline & $12-14$ & $3.10 \pm 0.20$ & $2.80 \pm 0.13$ & $3.30 \pm 0.12$ \\
\hline & $14-16$ & $7.71 \pm 0.13$ & $7.80 \pm 0.20$ & $7.50 \pm 0.12$ \\
\hline & $16-18$ & $8.32 \pm 0.10^{\mathrm{a}}$ & $5.24 \pm 0.50^{\mathrm{b}}$ & $6.90 \pm 0.70^{\mathrm{b}}$ \\
\hline & $18-20$ & $7.94 \pm 1.1$ & 8.200 .11 & $7.70 \pm 0.13$ \\
\hline \multirow{5}{*}{$\begin{array}{c}\text { FCRe } \\
\text { (g feed/g egg) }\end{array}$} & Overall mean & $5.10 \pm 0.13$ & $4.70 \pm 0.10$ & $4.70 \pm 0.20$ \\
\hline & $20-24$ & $5.10 \pm 0.30$ & $5.15 \pm 0.40$ & $5.10 \pm 0.32$ \\
\hline & $24-28$ & $3.73 \pm 0.02$ & $4.00 \pm 0.20$ & $3.67 \pm 0.30$ \\
\hline & $28-32$ & $3.30 \pm 0.09$ & $3.56 \pm 0.13$ & $3.70 \pm 0.10$ \\
\hline & $32-36$ & $3.34 \pm 0.08$ & $3.43 \pm 0.20$ & $3.36 \pm 0.12$ \\
\hline \multicolumn{2}{|r|}{ Overall mean } & $3.86 \pm 0.04$ & $4.03 \pm 0.1$ & $3.95 \pm 0.30$ \\
\hline
\end{tabular}

a-----b Means \pm standard error in the same row with different superscripts are significantly different $(\mathrm{P} \leq 0.05)$.

$\mathrm{C}, \mathrm{T} 1$ and $\mathrm{T} 2=$ Birds were reared under incandescent, fluorescent and saving light bulbs respectively.

\section{Carcass quality:}

Results in Table (4), showed no significant differences for the percentages of dressed carcass, drumsticks, femurs, breast, heart, gizzard and testes among all 
groups. The differences were significant $(\mathrm{P} \leq 0.05)$ for liver, giblets and ovary percentages. Birds of FL and SL groups had significantly $(\mathrm{P} \leq 0.05)$ the highest liver and giblets percentages as compared to the birds of IL group by 13.9 and $21.3 \%$ as well as 17.2 and $23.2 \%$, respectively. The obtained results are in partial agreement with the findings of Classen et al. (1991); Lilburn et al. (1992); Clarke et al. (1993); Hamilton and Kennie (1997), who reported that source and regimens of light had no effect on carcass quality. However, Karakaya et al. (2009) found that light source had significant effect on breast and drumstick muscles.

Table 4. Means $\pm \mathrm{SE}$ of carcass traits of Dandarawi chickens as affected by light source

\begin{tabular}{cccc}
\hline Traits & \multicolumn{3}{c}{ Treatments } \\
\cline { 2 - 4 } & C & T1 & T2 \\
\hline Live body weight, (g) & $1320.1 \pm 23.5^{\mathrm{b}}$ & $1420.7 \pm 26.4^{\mathrm{a}}$ & $1457.5 \pm 31.4^{\mathrm{a}}$ \\
Dressed carcass, (\%) & $69.2 \pm 0.60$ & $70.9 \pm 0.31$ & $70.1 \pm 0.61$ \\
Drumsticks, (\%) & $10.0 \pm 1.0$ & $10.3 \pm 0.24$ & $10.9 \pm 0.33$ \\
Femurs, (\%) & $10.0 \pm 0.62$ & $10.4 \pm 0.74$ & $10.6 \pm 0.34$ \\
Breast, (\%) & $11.4 \pm 0.91$ & $12.2 \pm 0.80$ & $12.4 \pm 0.73$ \\
Heart, (\%) & $0.79 \pm 0.02$ & $0.82 \pm 0.01$ & $0.82 \pm 0.02$ \\
Liver, (\%) & $2.85 \pm 0.12^{\mathrm{b}}$ & $3.31 \pm 0.10^{\mathrm{a}}$ & $3.44 \pm 0.06^{\mathrm{a}}$ \\
Gizzard, (\%) & $3.38 \pm 0.18$ & $3.52 \pm 0.23$ & $3.58 \pm 0.27$ \\
Giblets, (\%) & $6.02 \pm 0.26^{\mathrm{b}}$ & $7.65 \pm 0.30^{\mathrm{a}}$ & $7.84 \pm 0.24^{\mathrm{a}}$ \\
Testes, (\%) & $0.33 \pm 0.022$ & $0.28 \pm 0.023$ & $0.29 \pm 0.024$ \\
Ovary, (\%) & $0.92 \pm 0.06^{\mathrm{a}}$ & $0.59 \pm 0.08^{\mathrm{b}}$ & $0.66 \pm 0.05^{\mathrm{b}}$ \\
\hline
\end{tabular}

a-----b Means \pm standard error in the same row with different superscripts are significantly different $(\mathrm{P} \leq 0.05)$.

$\mathrm{C}, \mathrm{T} 1$ and $\mathrm{T} 2=$ Birds were reared under incandescent, fluorescent and saving light bulbs respectively.

Birds exposed to IL light showed significantly the highest ovary percentages $(\mathrm{P} \leq 0.05)$ as compared to the FL and SL groups by 35.9 and $28.3 \%$, respectively. There is a correlation between light and gonadal size and activity (Sudhakumari et al., 2001). These results are in harmony with the findings of Lewis and Morrish (2000). They concluded that red light had more activity and aggressive behaviour in turkeys and chickens than blue or green light. Also, red light produced sexually more stimulatory and blue light had calming effects. Opposite results, were reported by Harrison et al. (1969) who stated that pullets maintained under blue or green light reached sexual maturity 4 to $5 \mathrm{~d}$ earlier than birds maintained on red or white light. Also, Lewis et al. (2007) found that the average age at first egg was $1 \mathrm{~d}$ earlier for birds reared under white light. However, Pyrzak et al. (1986) showed no difference in the rate of gonadal maturation.

\section{Egg production (EP):}

The data presented in Table (5) revealed insignificant differences $(\mathrm{P}>0.05)$ in the average of egg weight (EW), egg number (EN) and hen day egg production (HDP) among birds in the experimental groups at all studied ages except from 28-32 weeks of age in the EN and HDP. The averages of EN and HDP for the control (C) significantly $(\mathrm{P} \leq 0.05)$ exceeded those of $\mathrm{T} 1$ and $\mathrm{T} 2$, during the period from 28-32 weeks of age by $6.9 ; 6.9$ and $12.1 ; 11.9 \%$, respectively. The total EN for C exceeded 
significantly $(\mathrm{P} \leq 0.05)$ that of $\mathrm{T} 1$ and $\mathrm{T} 2$ by 3.9 and $3.0 \%$, respectively, also, the overall mean of HDP for the $\mathrm{C}$ group significantly $(\mathrm{P} \leq 0.05)$ surpassed those of the $\mathrm{T} 1$ and $\mathrm{T} 2$ groups by 7.0 and $6.2 \%$, respectively.

Table 5. Means \pm SE of egg number, hen day egg production and egg weight for Dandarawi chicken as affected by light source

\begin{tabular}{|c|c|c|c|c|}
\hline \multirow{2}{*}{ Traits } & \multirow{2}{*}{ Periods } & \multicolumn{3}{|c|}{ Treatments } \\
\hline & & $\mathbf{C}$ & T1 & T2 \\
\hline \multirow{5}{*}{$\begin{array}{c}\text { Egg number } \\
\text { (egg/hen/28 days) }\end{array}$} & P1 (20-24 w) & $10.9 \pm 0.49$ & $10.7 \pm 0.79$ & $10.8 \pm 0.73$ \\
\hline & P2 (24-28 w) & $14.5 \pm 0.30$ & $13.9 \pm 0.52$ & $15.0 \pm 0.75$ \\
\hline & P3 (28-32 w) & $17.3^{\mathrm{a}} \pm 0.38$ & $16.1^{\mathrm{ab}} \pm 0.32$ & $15.2^{\mathrm{b}} \pm 0.49$ \\
\hline & P4 (32-36 w) & $17.0 \pm 0.36$ & $16.7 \pm 0.47$ & $16.9 \pm 0.35$ \\
\hline & Total & $59.7^{\mathrm{a}} \pm 0.50$ & $57.4^{\mathrm{b}} \pm 0.68$ & $57.9^{\mathrm{ab}} \pm 0.32$ \\
\hline \multirow{5}{*}{ Egg weight (g) } & P1 (20-24 w) & $42.4 \pm 0.34$ & $41.9 \pm 0.42$ & $42.0 \pm 0.36$ \\
\hline & P2 (24-28 w) & $43.6 \pm 0.38$ & $42.8 \pm 0.58$ & $43.3 \pm 0.38$ \\
\hline & P3 (28-32 w) & $44.4 \pm 0.24$ & $43.4 \pm 0.76$ & $44.1 \pm 0.24$ \\
\hline & P4 (32-36 w) & $45.9 \pm 0.26$ & $44.8 \pm 0.35$ & $45.6 \pm 0.27$ \\
\hline & $\begin{array}{c}\text { Overall } \\
\text { mean }\end{array}$ & $44.1 \pm 0.25$ & $43.3 \pm 0.40$ & $43.7 \pm 0.26$ \\
\hline \multirow{5}{*}{ HDP (\%) } & P1 (20-24 w) & $45.6 \pm 2.01$ & $44.4 \pm 3.30$ & $45.1 \pm 3.00$ \\
\hline & P2 (24-28 w) & $64.6 \pm 1.20$ & $57.8 \pm 2.20$ & $62.4 \pm 3.14$ \\
\hline & P3 (28-32 w) & $72.1^{\mathrm{a}} \pm 1.70$ & $67.1^{\mathrm{ab}} \pm 1.34$ & $63.5^{\mathrm{b}} \pm 2.04$ \\
\hline & P4 (32-36 w) & $75.0 \pm 1.50$ & $69.7 \pm 1.94$ & $70.4 \pm 1.50$ \\
\hline & $\begin{array}{c}\text { Overall } \\
\text { mean }\end{array}$ & $64.3^{\mathrm{a}} \pm 0.52$ & $59.8^{b} \pm 0.71$ & $60.3^{\mathrm{b}} \pm 0.33$ \\
\hline
\end{tabular}

a-----b Means \pm standard error in the same row with different superscripts are significantly different $(\mathrm{P} \leq 0.05)$.

$\mathrm{C}, \mathrm{T} 1$ and $\mathrm{T} 2=$ Birds were reared under incandescent, fluorescent and saving light bulbs respectively.

The obtained results for egg production coincided with the observations by Felts et al. (1990) who found that egg weight, was unaffected by light-source treatment. However HDP was significantly higher for females given FL than for those provided with IL. Also, Felts et al. (1992) found that hens subjected to FL lights consistently laid more eggs than those under IL lights. The authors found that red light caused hens to lay larger eggs with great quantities of albumen per egg. Pyrzak et al. (1987) reported that eggs laid under blue or green light were consistently larger then those laid under red light. The behavior and performance of bird can be manipulated by the use of specific colours, especially those with long waves, such as red, orange, yellow, green and blue. Harrison et al. (1969) observed that pullets maintained under blue or green light reached sexual maturity 4 to $5 \mathrm{~d}$ earlier than birds maintained on red or white light but subsequently had inferior egg production. Whereas egg production was similar for other groups of birds that had been reared on blue, green, red, or white light prior to a transfer to white light at $20 \mathrm{wk}$. Pyrzak et al. (1986) found no difference in the rate of egg production in hens illuminated with blue, green, or red monochromatic light compared with others illuminated with white light. However, 
Harrison et al. (1969) reported that egg weight tended to be lower for birds illuminated with blue or green light compared with red or white light. In contrast, Pyrzak et al. (1984) reported that egg weight for hens illuminated with green light was significantly heavier than egg weight for those exposed to red light.

On the other hand, Rozenboim et al. (1998) found that light source had no effect on egg production. Jones et al. (1982), Siopes (1984), Pyrzak and Siopes (1986), Lewis and Morris (2000) and Lewis et al. (2007) revealed that the use of different light colors and sources had no effect on egg production or egg weight.

\section{Egg quality:}

Data in Table (6), show no significant differences $(\mathrm{P}>0.05)$ in the average egg weight (AEW), egg shape index (ESI), Haugh Units (HU) and egg components (albumen $\%$, yolk\%, shell\%) among all groups at all studied ages. However, there were significant differences $(\mathrm{P} \leq 0.05)$ in egg yolk index $(\mathrm{EYI})$ and shell thickness (ST) values among the birds in the different experimental groups. The averages EYI of $\mathrm{T} 1$ and $\mathrm{T} 2$ were significantly $(\mathrm{P} \leq 0.05)$ higher than those of the $\mathrm{C}$ by 3.3 and $3.1 \%$, respectively. With regard to shell thickness (ST), the average ST of T2 group was significantly $(\mathrm{P} \leq 0.05)$ higher than those of the $\mathrm{C}$ and $\mathrm{T} 1$ by 5.7 and $3.7 \%$, respectively.

Table 6. Means \pm SE of egg quality parameters and egg components for Dandarawi chickens as affected by light source

\begin{tabular}{lccc}
\hline \multirow{2}{*}{\multicolumn{1}{c}{ Traits }} & \multicolumn{3}{c}{ Treatments } \\
\cline { 2 - 4 } & C & T1 & T2 \\
\hline Egg weight (g) & $43.53 \pm 0.33$ & $42.84 \pm 0.40$ & $43.47 \pm 0.40$ \\
Egg shape index (\%) & $77.70 \pm 0.32$ & $76.60 \pm 0.47$ & $77.10 \pm 0.47$ \\
Egg yolk index (\%) & $46.80^{\mathrm{b}} \pm 0.25$ & $48.40^{\mathrm{a}} \pm 0.40$ & $48.30^{\mathrm{a}} \pm 0.40$ \\
Haugh units & $80.03 \pm 1.12$ & $80.20 \pm 0.70$ & $81.00 \pm 0.70$ \\
Egg shell thickness (x 0.01 mm) & $33.00^{\mathrm{b}} \pm 0.22$ & $33.70^{\mathrm{b}} \pm 0.24$ & $35.00^{\mathrm{a}} \pm 0.24$ \\
Albumen (\%) & $54.09 \pm 0.20$ & $54.18 \pm 0.37$ & $53.87 \pm 0.37$ \\
Yolk (\%) & $33.08 \pm 0.26$ & $32.97 \pm 0.26$ & $33.18 \pm 0.26$ \\
Shell (\%) & $11.63 \pm 0.34$ & $11.79 \pm 0.22$ & $11.86 \pm 0.19$ \\
\hline
\end{tabular}

a-----b Means \pm standard error in the same row with different superscripts are significantly different $(\mathrm{P} \leq 0.05)$.

$\mathrm{C}, \mathrm{T} 1$ and $\mathrm{T} 2=\mathrm{Birds}$ were reared under incandescent, fluorescent and saving light bulbs respectively.

Chicken eye can discriminate light colors, and different light wavelengths affect egg quality. Egg weight in the red light treatment was less than those in other lights. The egg length and egg width under blue light treatment became shorter, and the egg width under red light treatment became shorter with age; the egg quality under green light conditions was found to be the best (Er et al., 2007). The obtained results are in agreement with observations of Pyrzak et al. (1987) who found that light source had the effect on the egg quality for chicken that is different from the reports of Pyrzak and Siopes (1986) for turkeys. Also, Rozenboim et al. (1998) found that light source had no effect on quality. Lewis et al. (2007) found that there were no significant differences between the different light source for Albumen height and shell weight. So, our results are in agreement with Felts et al. (1990 and 1992). They reported that egg weight, and egg specific gravity were unaffected by either the adolescent or breeder light-source treatment. However, Pyrzak et al. (1987) suggested that egg weight was affected by the light spectrum. 


\section{Fertility and hatchability:}

The data presented in Table (7), show no significant differences $(\mathrm{P}>0.05)$ in fertility and hatchability (\%) among the experimental groups. These results are in agreement with the findings of Scott and Siopes (1994) in turkey hens and Felts et al. (1990 and 1992) who found that fertility, hatchability were unaffected by either the adolescent or breeder light-source treatment. Also, Lewis and Morris (2000) found that light source had no effect upon hatchability or any fertility parameter.

Table 7. Means \pm SE of fertility (\%) and hatchability (\%) of Dandarawi chickens as affected by light source

\begin{tabular}{|c|c|c|c|c|c|c|}
\hline \multirow{2}{*}{$\begin{array}{c}\text { Age } \\
\text { (in weeks) }\end{array}$} & \multicolumn{3}{|c|}{ Fertility } & \multicolumn{3}{|c|}{ Hatchability } \\
\hline & C & T1 & T2 & $\mathbf{C}$ & T1 & T2 \\
\hline 24 & $84.10 \pm 2.3$ & $84.61 \pm 1.3$ & $84.85 \pm 2.0$ & $68.95 \pm 0.94$ & $67.27 \pm 0.52$ & $66.95 \pm 0.51$ \\
\hline 28 & $86.31 \pm 2.2$ & $90.65 \pm 1.2$ & $87.18 \pm 2.2$ & $69.64 \pm 0.64$ & $71.40 \pm 0.82$ & $70.00 \pm 0.54$ \\
\hline 32 & $87.50 \pm 2.2$ & $90.26 \pm 1.2$ & $90.51 \pm 2.1$ & $71.59 \pm 0.50$ & $72.79 \pm 1.2$ & $69.89 \pm 0.57$ \\
\hline 36 & $89.04 \pm 1.8$ & $90.35 \pm 1.6$ & $91.89 \pm 2.7$ & $72.17 \pm 0.50$ & $74.20 \pm 0.79$ & $72.15 \pm 1.9$ \\
\hline $\begin{array}{c}\text { Overall } \\
\text { mean }\end{array}$ & $86.73 \pm 2.1$ & $88.00 \pm 1.2$ & $89.23 \pm 2.1$ & $70.60 \pm 0.51$ & $71.42 \pm 0.80$ & $69.74 \pm 0.97$ \\
\hline
\end{tabular}

No significant differences were observed $(\mathrm{P}>0.05)$.

$\mathrm{C}$, $\mathrm{T} 1$ and $\mathrm{T} 2=$ Birds were reared under incandescent, fluorescent and saving light bulbs respectively.

\section{Leg problems:}

From the presented data in Table (8), it could be observed that the leg problem percentages of IL, FL and SL groups were $0.8,0.1$ and $0.8 \%$, as well as $0.4,0.4$ and $0.5 \%$ for growing and laying periods, respectively. Similar findings were reported by Kristensen et al. (2006) who found that light source had no effect on the severity of the gait-score or hock-burns and leg health of broiler chickens. Contrary, Hulan and Proudfoot (1987) found that incidence of angular deformity and total leg abnormalities were lower and tibial dyschondroplasia was higher for roasters reared under fluorescent as opposed to incandescent light. Prayitno et al. (1997a) found that rearing meat chickens in bright red light increases activity, which reduces locomotion disorders in the late rearing period.

\section{8- Mortality:}

The data presented in Table (8), showed that, the mortality rate of IL, FL and SL groups were $2.5,3.13$ and $2.81 \%$ as well as $3.83,4.31$ and $3.45 \%$ for the growing and laying periods, respectively. These results are in accordance with the obtained findings by Leighton et al. (1989) who observed greater mortality in birds under fluorescent light. Also, Abdul Ghuffar et al. (2009) indicated that light source had significant $(\mathrm{P} \leq 0.05)$ effect on mortality rate. On the other hand blue, green and yellow wavelengths have positive while orange and red wavelengths have negative effects on broiler performance (Hakan and Ali, 2005). However, some other scientists observed that light source had no significant effect on mortality (Hulan and Proudfoot, 1987; Zimmermann, 1988; Rodenburg and Middelkoop, 2003; Kristensen, 2006; Xie et al., 2008) found that green light and blue light enhance the immune 
response better than red light, and that blue light may play a role in alleviating the stress response in broilers. Hulan and Proudfoot (1987) found that light source had no significant effect on mortality. It was concluded that light color can have an effect on humoral immune responses. Scott and Siopes (1994) found that light color had no effect on the total number of erythrocytes, leukocytes, or plasma corticosterone levels. While, cutaneous basophil hypersensitivity, number of heterophils, and heterophil/lymphocyte ratios were significantly affected by light color.

Table 8. Means \pm SE of leg problems, bone measurements and mortality rate of Dandarawi chickens as affected by light source

\begin{tabular}{ccccc}
\hline \multirow{2}{*}{ Traits } & \multirow{2}{*}{ Periods } & \multicolumn{3}{c}{ Treatments } \\
\cline { 3 - 5 } & & $\mathbf{C}$ & T1 & T2 \\
\hline \multirow{2}{*}{ Leg problems (\%) } & $4-20 \mathrm{w}$ & 0.8 & 1.0 & 0.8 \\
& $20-36 \mathrm{w}$ & 0.4 & 0.4 & 0.5 \\
\hline \multirow{2}{*}{ Mortality rate (\%) } & $4-20 \mathrm{w}$ & 2.50 & 3.13 & 2.81 \\
& $20-36 \mathrm{w}$ & 3.88 & 4.31 & 3.45 \\
\hline
\end{tabular}

$\mathrm{C}, \mathrm{T} 1$ and T2= Birds were reared under incandescent, fluorescent and saving light bulbs respectively.

\section{Economical efficiency (EE):}

Results in Table (9) indicate that the economical efficiency of the FL and SL groups exceeded the control group (IL) by 26.4 and $36.1 \%$, respectively during the growing period. However, the IL group increased by 12.9 and $11.4 \%$ as well as by 4.1 and $1.4 \%$ for table egg and fertile egg production, respectively compared to the other groups (FL and SL). These results are in partial agreement with those obtained by Abdul Ghuffar, et al. (2009) and Buyse et al. (1996) who indicated that light source should be more energy efficient and has long life to replace incandescent lighting in poultry houses. Also, Hulan and Proudfoot (1987) and Hajra et al. (2009) concluded that fluorescent light was better than incandescent light for commercial broiler production. It could be concluded that the performance FL and SL groups exceeded the IL during the growing period. However, the IL group increased for table egg and fertile egg production compared to the FL and SL groups. So, it is the recommended source during the growing period. 
Table 9. Economical efficiency for Dandarawi chickens as affected by light source

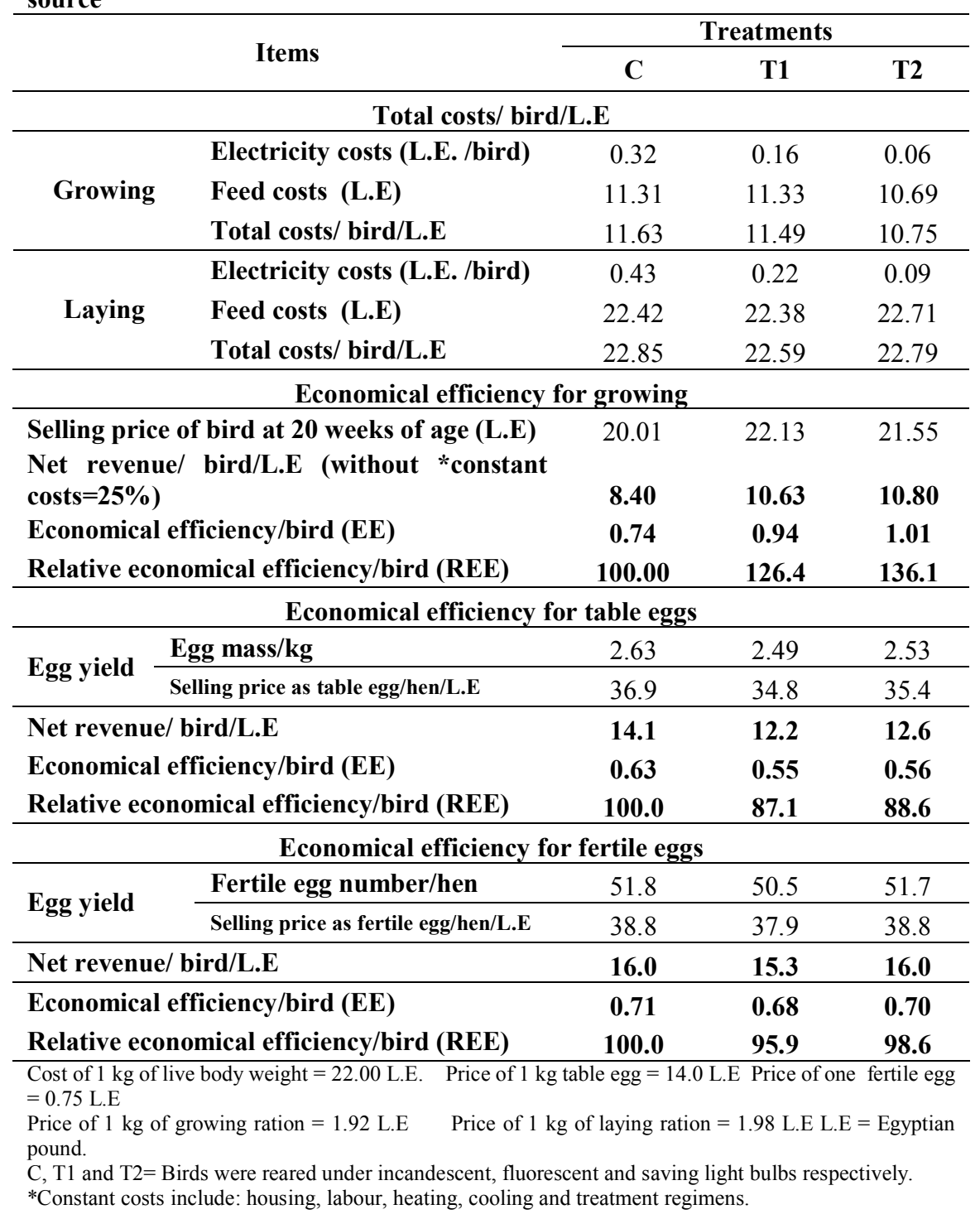




\section{REFERENCES}

Abdul Ghuffar, Khalil-ur-Rahman, Muhammad Siddque, Fawwad Ahmad and Mahmood A. Khan, 2009. Impact of various lighting source (incandescent, fluorescent, metal halide and high pressure sodium) on the production performance of chicken broilers. Pak. J. Agri. Sci., Vol. 46;40-45.

Andrews D.K. and N.G. Zimmerman, 1990. A comparison of energy efficient broiler house lighting sources and photoperiods. Poult. Sci. 69:1471-1479.

Brant A.W. and H.L. Hrader, 1952. How to measure internal egg quality? Bureau of Animal Industry. Agric. Res. Administration, U.S. Dept. of Agric., Circular P. A. 202.

Buyse J., P.C.M. Simons, F.M.G. Boshouwers and E. Decuypere, 1996. Effect of intermittent lighting, light intensity and source on the performance and welfare of broilers. World's Poult. Sci. J., 52: 121-130.

Carson J.R., W.A. Junnila and B.F. Bacon,1958. Sexual maturity and productivity in the chicken as affected by the quality of illumination during the growing period. Poult. Sci. 37:102-112.

Clarke J.P., P.R. Ferket, R.G. Elkin, C.D. Mcdaniel J.P., Mcmurtry, M. Freed, K.K. Krueger, B.A. Watkins and P.Y. Hester, 1993. Effect of dietary protein restriction and intermittent lighting. 1. Effects on lameness and performance of male turkeys. Poult. Sci. J., 2: 2131-2143

Classen H.L., C. Riddell and F.E. Robinson, 1991. Effects of increasing photoperiod length on performance and health of broiler chickens. Br. Poult. Sci., J., 32: 2129.

Darre M.J. 1986. Energy Efficient Fluorescent Lights Reduce Electric Bills for Poultrymen. Poultry Digest 44:108-113.

Darre M.J. and J.S Rock, 1995. Compact fluorescent lamps under commercial poultry house conditions. J. Appl. Poult. Res. 4:105-108.

Denbow D.M., A.T. Leighton and R.M. Hulet, 1990. Effect of light sources and light intensity on growth performance and behaviour of female turkeys. Br. Poult. Sci. J., 31: 439-443

Doyon G., C.M., Bernier, R.M.G., Hamilton, F., Eagtaigns and C.T. Ramdald, 1986. Egg quality. 2. Albumen quality of egg from five commercial strains of White Leghorn hens during one year of lay. Poult. Sci., 65: $63-66$.

Duncan D.B., 1955. Multiple range and multiple tests. Biometrics, 11:1-42.

Er Z. Wang, J. Cao and Y. Chen, 2007. Effect of Monochromatic Light on the Egg Quality of Laying Hens. Appl. Poult. res. 16:605-612.

Felts J.V., AT. Jr. Leighton, D.M. Denbow, RM Hulet, 1990. Influence of light sources on the growth and reproduction of large white turkeys. Poult. Sci., 69: 576-83.

Felts J.V., AT. Jr. Leighton, D.M. Denbow and R.M. Hulet, 1992. Effects of light sources and the presence or absence of males on reproduction of female breeder turkeys. Poult. Sci., 71:17-22.

Hajra D.K., K. Shive, J.P Korde., A.K Ghosh, D. Kumar, 2009. Effect of light source on growth and economics of commercial broiler production. Indian $\mathrm{J}$ of Poult. Sci., 44: Issue:2.

Hakan, B. and A. Ali., 2005. Effects of light wavelength on broiler performance. Hayvansal Üretim 46: 22-32.

Hamilton, R.M.G. and J. Kennie, 1997. The effects of lighting program. Ingredient particle size and feed form on the performance of broiler turkey. Canadian J. of Animal Sci., 77 3, 503-508. 
Harrison P.C., J. McGinnis, G. Schumaier and J. Lauber, 1969. Sexual maturity and subsequent reproductive performance of white leghorn chickens subjected to different parts of the light spectrum. Poult. Sci., 48:878-883.

Hulan H.W. and F.G. Proudfoot, 1987. Effects of light source, ambient temperature, and dietary energy source on the general performance and incidence of leg abnormalities of roaster chickens. Poult. Sci., 66: 645-651.

Jones, J.E., B.L. Hughes, R.J. Thurston and R.S. Hess, 1982. The effects of red and white light on egg production and feed consumption in broiler. Poult. Sci., 61(9): 1930-1932.

Karakaya M., S.S. Parlat, M.T. Yilmaz, I. Yildirim, B. Ozalp, 2009. Growth performance and quality properties of meat from broiler chickens reared under different monochromatic light sources. Br. Poult. Sci. J., 50: 76 - 82.

Knisley R. Joseph, 1990. Updating light sources for new and existing facilities. Electrical Construction and Maintenance 89: 49-60.

Kristensen H.H., G.C. Perry, N.B. Prescott, J. Ladewig, A.K. Ersbøll, C.and M. Wathes, 2006. Leg health and performance of broiler chickens reared in different light environments. Br. Poult. Sci. J., 47: 257-263.

Leighton, A.T., R.M. Hulet and D.M. Denbow, 1989. Effect of light sources and light intensity on growth performance and behavior of male turkeys. British Poult. Sci. 30: 563-574.

Lewis P. D., L. Caston and S. Leeson, 2007. Green light during rearing does not significantly affect the performance of egg-type pullets in the laying phase. Poult. Sci. J., 86:739-743.

Lewis P.D. and T.R. Morris, 1998. Responses of domestic poultry to various light sources. Poult. Sci., 54: 7-25.

Lewis P.D., and T.R. Morris, 2000. Poultry and coloured light. World's Poult. Sci., 56:189-208.

Lilburn, M.S., P.A. Renner and N.B. Anthony, 1992. Interaction between step-up versus step-down lighting from four to sixteen weeks on growth and development in turkey hens from two commercial breeds. Poult. Sci., 71: 419- 426.

Mench J.A., 1998. Environmental enrichment and the importance of exploratory behavior. Pages 30-46 in Second Nature, Environmental Enrichment for Captive Animals. D. J. Shepherdson, J. D. Mellen, and M. Hutchins, ed. Smithsonian Institution, Washington, DC.

Morris T.R., 2004. Environmental control for layers. World's Poult. Sci. 60:163-175.

National Research Council, 1994. Nutrient Requirements of Poultry. $9^{\text {th }}$ rev. ed. National Academy Press, Washington, D.C.

Newberry R.C., 1995. Environmental enrichment: increasing the biological relevance of captive environments. Appl. Animal Behav. Sci., 44: 229-243.

Prayitno D.S, C.J. Phillips and DK Stokes, 1997a. The effects of color and intensity of light on behavior and leg disorders in broiler chickens. Poult Sci., 76:16741681.

Prayitno D.S., C.J. Phillips and H. Omed, 1997b. The effects of color of lighting on the behaviour and production of meat chickens. Poult. Sci., 76:452-457.

Pyrzak R., and T.D. Siopes, 1986. The effect of color light on egg quality of turkey hens in cages. Poult. Sci., 65:1262-1267. 
Pyrzak, R., N. Snapir, G. Goodman, and M. Perek, 1984. The influence of light quality on egg production and egg quality of the domestic hen. Poult. Sci. 63(Suppl.):30. (Abstr.).

Pyrzak R., N. Snapir, G. Goodman and M. Perek, 1987. The effect of light wavelength on the production and quality of eggs of the domestic hen. Theriogenology 28:947-960.

Pyrzak R., N. Snapir, G. Goodman, E. Arnon, and M. Perek, 1986. The influence of light quality on initiation of egg laying by hens. Poult. Sci. 65:190-193.

Reddy P.M., V.R. Reddy, C.V. Reddy and P.S.P. Rap, 1979. Egg weight, shape index and hatchability in Khaki Campbell duck egg. Ind. J. Poult. Sci., 14: 26-31.

Rodenburg J.V.H. and J.H.V. Middelkoop, 2003. Effect of coloured light on production and welfare traits in broilers. T. Applied Research, Animal Sciences Group, Wageningen UR, P.O. Box 2176, 8203 AD Lelystad, The Netherlands.

Rozenboim I., I. Biran, Y. Chaiseha, S. Yahav, A. Rosenstrauch, D. Sklan and O. Halevy, 2004. The effect of a green and blue monochromatic light combination on broiler growth and development. Poult. Sci., 83: 842-845.

Rozenboim I., E. Zilberman, and G. Gvaryahu, 1998. New monochromatic light source for laying hens. Poult. Sci., 77:1695-1698.

Rozenboim I., I. Biran, Z. Uni, B. Robinzon and O. Halevy, 1999. The effect of monochromatic light on broiler growth and development. Poult. Sci., 78: 135-138.

SAS, 1996. SAS User's Guide, statistics (6.2th ed.) Cary NC: SAS Institute Inc.

Scheideler S.E., 1990. Research Note: Effect of various light sources on broiler performance and efficiency of production under commercial conditions. Poult. Sci., 69:1030-1033.

Scott R.P and T.D. Siopes, 1994. Light color: effect on blood cells, immune function and stress status in turkey hens. Comp Biochem Physiol Comp Physiol.108:161-8

Siopes T.D., 1984. The effect of full-spectrum fluorescent lighting on reproductive traits of caged turkey hens. Poult. Sci., 63: 1122-1128.

Stoianov P.D. Baikov and G.A. Georqiev, 1978. Effect of fluorescent lighting on the growth of broiler chicken. Vet. Med. Nauki 15: 89-95.

Sudhakumari C.C., C. Haldar and B. Senthilkumaran, 2001. Seasonal changes in adrenal and gonadal activity in the quail Perdicula asiatica: Involvement of the pineal gland. Comp. Biochem. Physiol. B, Biochem. Mol. Biol. 128:793-804.

Tarihi T., 1996. The Effects of light color and lighting regimes on the quail growth and carcass traits. Tr. J. Veterinary and Animal Sciences 22: 103-110.

Wabeck C.J. and W.C. Skoglund, 1974. Influence of radiant energy from fluorescent light sources on growth, mortality and feed conversion of broilers. Poult. Sci., 53:2055-2059.

Wemelsfelder F. and L. Birke, 1997. Environmental challenge. Pages 35-47 in Animal Welfare. M. C. Appleby and B. O. Hughes, ed. CAB International, Wallingford, UK.

Widowski T.M., L.J. Keeling and I.J.H. Duncan, 1992. The preferences of hens for compact fluorescent over incandescent lighting. Canadian. J. Animal Sci., 72:203-211.

Xie D., Z. X. Wang, Y. L. Dong, J. Cao, J. F. Wang, J. L. Chen and Y. X. Chen, 2008. Effects of Monochromatic Light on Immune Response of Broilers. Poult. Sci., 87:1535-1539.

Zimmermann, 1988. Broiler performance when reared under various light sources. Poult. Sci., J., 67: 43-51. 
إستخدام اللمبات الموفرة كمصدر إضاعة إقتصادي بديل في تربية الدجاج الدندراوى

$$
\text { قحمد فرغلى علم الدين فرغلى و محمود على عبد النبي }
$$

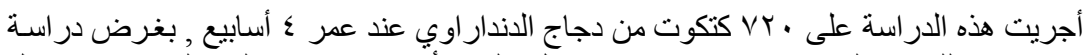

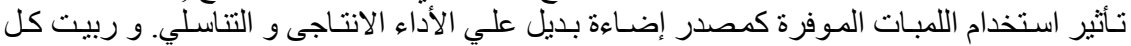

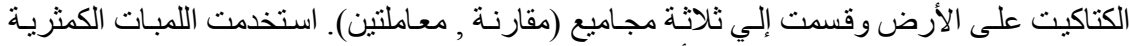

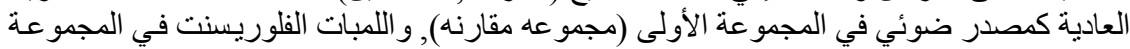

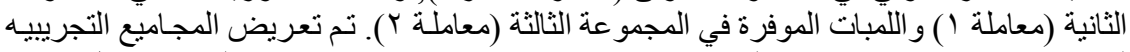

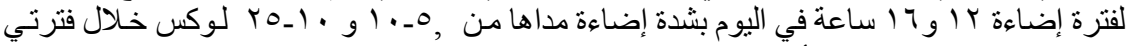

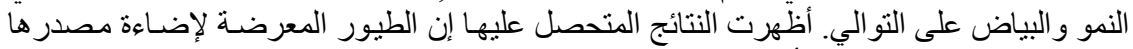

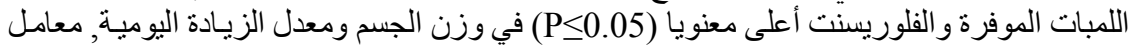

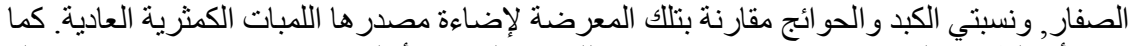

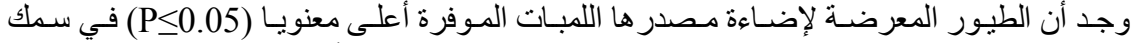

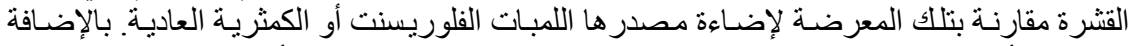

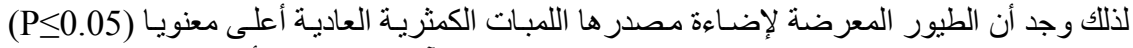

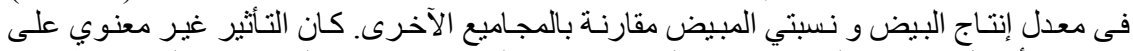

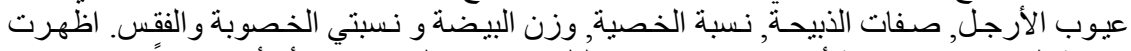

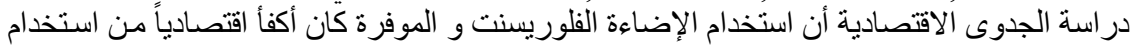

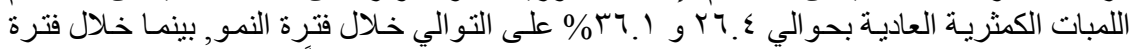

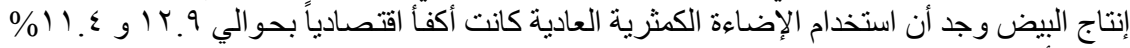

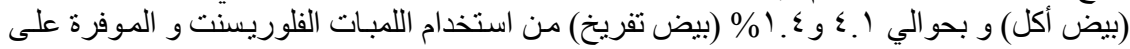

